\section{'IT'S THE END OF THE WORLD AS WE KNOW IT - HUMAN DISPLACEMENT, LOSS OF STATES AND CLIMATE CHANGE"}

In the last few years, headlines such as "Climate Change will cause "refugee crisis"” and "50 million environmental refugees by end of decade, UN warns" have been appearing more and more frequently in the mainstream media. Citing droughts and water shortages, storm surges and floods and sea-level rise, humanitarian aid and environmental organisations are drawing public attention to the projections that anywhere from 25 million to over 200 million people may be displaced as a result of climate change in the coming century.

Climate change is a reality. In December 2007, the Intergovernmental Panel on Climate Change (IPCC) presented its latest findings to the parties to the United Nations Framework Convention on Climate Change (UNFCCC) assembled in Bali, Indonesia. The IPCC Synthesis Report states "Warming of the climate system is unequivocal, as is now evident from observations of increases in average air and ocean temperatures, widespread melting of snow and ice, and rising global average sea level." The IPCC estimates global average sea level rise by the end of the 21 st century in the range of 0.18 and 0.59 meters. However, some scientists are concerned that accelerated melting of the polar ice sheets, on century rather than millennial time scales, could cause metres of sea level rise, resulting in major changes to coastlines, and inundation of low-lying areas, with the greatest effects in river deltas and low-lying islands.

Small island countries in the Pacific, Caribbean and Indian Oceans are among those places most at risk. For example, the Maldives, in the Indian Ocean, consists of some 1,300 small islands; 50 per cent to 80 per cent of the Maldives' land area is less than one metre above sea level. In the Pacific, Tuvalu consists of nine atolls and reef islands, virtually all of which are less than two meters above sea level. Sea level rise has the potential to disrupt all aspects of economic and social life on these islands, through direct impacts upon livelihoods and through the effects of offisland migration, which drains human resources and disrupts cultural ties. Taken to its extreme, the loss of island territory threatens the very existence of sovereign nations over time.

The possibility, and in some instances the inevitability, that people will be forced to abandon their traditional homes and migrate either within their own country or to other countries raises a number of difficult questions about the treatment of these people. Are they "refugees" as claimed by the media? What rights should they be afforded at home and abroad? Should they be compensated for the loss of their property and livelihoods?

The terms "environmental refugee" and "climate refugee" are increasingly being used in the popular

\begin{tabular}{|c|c|}
\hline Articles & \\
\hline $\begin{array}{l}\text { Law reform in England and Wales: a shattered dream } \\
\text { or triumph of political vision? }\end{array}$ & 3 \\
\hline Legal approaches to the burial rights of a surviving wife & 12 \\
\hline Institute News & 16 \\
\hline Articles (cont'd) & \\
\hline Comparative law at a crossroads & 21 \\
\hline $\begin{array}{l}\text { Meaning and reference: } \\
\text { the interpretation of general terms }\end{array}$ & 24 \\
\hline $\begin{array}{l}\text { Private companies in the Netherlands: } \\
\text { proposals for law reform }\end{array}$ & 30 \\
\hline
\end{tabular}

literature to describe people compelled to leave their traditional homes as a result of marked environmental disruption. However, the United Nations High Commission for Refugees (UNHCR) has consistently rejected the case for categorising environmental causes as grounds for refugee status. In the UNHCR's view, the conditions for environmental displacement do not align with the characteristics that may trigger refugee status under the UN Convention Relating to the Status of Refugees 1951. Those characteristics relate to actual or threatened persecution based on race, religion, nationality or affiliation and threats to life and personal freedom.

International refugee law provides a framework for the treatment of refugees and this status affords people so characterised certain privileged rights in the country to which they have fled. Similar rights do not accrue to environmental or economic migrants. National migration policies may, in contrast, actually hinder the legal movement of those people most vulnerable to environmental disruption, such as the aged, children and the poor.

In 2000, the government of Tuvalu made a public plea to its developed Pacific neighbours to take in Tuvaluan residents if rising sea levels reached the point that evacuation would be essential. At present, the New Zealand government accepts a small annual quota of Tuvaluan migrants under its Pacific Access visa category. This category is not unusual in the context of traditional migration law - it is conditional on the applicants meeting criteria based on age, employment opportunities and proficiency in English. This raises the question of who will take in those people who will not ordinarily qualify for entry under traditional migration rules; and what new criteria might be developed to accommodate this special situation. In 2007, Australian Senator Kerry Nettle of the Greens Party introduced the Climate Refugees Visa Bill 2007 into the Senate. The Bill proposed the establishment of a new class of visa to be known as the "climate change refugee visa" which could be granted to persons who has been displaced as a result of a "climate change induced 
environmental disaster". Although the Bill was not passed, it highlighted a growing awareness of the need for new legal frameworks to provide for the orderly resettlement of those forced to migrate as a result of climate change impacts.

Most people, whether on small islands, in coastal deltas, or in arctic communities, do not want to be forced to leave their homes. If this occurs as a result of climate change, we will have seen a complete failure of the international community to protect those most vulnerable. In 2005 the Inuit Circumpolar Conference (ICC) brought a case in the Inter-American Commission of Human Rights, petitioning the court to remedy violations of the American Declaration of the Rights and Duties of Man by the United States of America. The Inuit, the traditional inhabitants of the Arctic region of North America and Greenland, alleged that the USA has violated a number of their rights encapsulated in the International Covenant on Civil and Political Rights, the International Covenant on Economic, Social and Cultural Rights and the American Declaration. In particular, they alleged that their rights to practice and enjoy the benefits of their culture, to use and enjoy traditional lands, to enjoy personal property, to maintain cultural intellectual property, the rights to health and life, the rights to residence and the inviolability of the home and the right to means of subsistence, were being infringed. The ICC claimed that the USA, as the world's largest emitter of greenhouse gases, should be accountable for these violations.

Although the Commission chose not to resolve the issues raised, the petition succeeded in drawing attention to issues of long-term liability for climate change and the obligation to protect those most vulnerable to climate change. Climate change raises interesting questions about the extent to which human rights obligations might be owed by one state to the citizens of another, whether compensation should be payable for a violation of rights and the extent to which the international community might be able to intervene to protect certain rights. Generally, responsibility for human rights protection is attributed to individual states and extends to all persons within that state's territory or jurisdiction. However, in most developing countries, the state is not directly responsible for the impacts of climate change and the potential violation of rights associated with the impacts of global warming.

In addition to the human dimension, climate change and sea-level rise also raise a number of serious issues about state sovereignty. In particular - can a country continue to exist as a sovereign state if it no longer has territory? And how will changes to its territory affect economic and political dynamics within the global system?

Underpinning the concept of statehood is the existence of territory and population. Rising sea levels threaten the existence of territory and the viability of local populations.
Whilst international law has addressed the consequences of the disillusion of a state and the process of state succession, it has never before been faced with questions of state disappearance. Nation states have certain rights, powers, capacities and obligations. If territory is lost, how are those rights, powers, capacities and obligations affected?

For coastal and island states, rights over the sea are also fundamentally important as they increase the resource base of the state. The United Nations Convention on the Law of the Sea prescribes limits for the territorial sea, contiguous zone, continental shelf and exclusive economic zone (EEZ) for coastal states. The extent of a country's territorial sea is measured from the low-water mark along the coast. In the case of islands situated on atolls or of islands having fringing reefs, the baseline for measuring the breadth of the territorial sea is the seaward low-water line of the reef. A valid claim over territorial waters, continental shelves and an EEZ give a state right to exploit the natural resource base of the waters and seabed, including fisheries and minerals.

Changes to coastlines can dramatically affect the ability of a state to claim associated marine territory and resources. Control over waterways also has important geopolitical consequences. The recent flurry of activity in the Arctic to stake out territory is a prime example of this. Climate change is expected to result in melting of Arctic ice, leading to the appearance of some land masses and disappearance of others and the opening up of waterways creating new opportunities to explore and exploit the resources of the area. States such as the Russian Federation, Canada, the USA, Norway and Denmark are all involved in a scramble for territory in the Arctic based upon where each sees the limits of their land, continental shelf or islands. The USA, Canada and the EU are also disputing the status of the North-West passage which is likely to become more freely navigable if warming continues.

Climate change throws up a number of challenges in respect of territorial claims, how resources are distributed amongst countries and how people forced to migrate will be resettled and treated. Many of these situations are unprecedented in international law and most of the questions posed here do not have any clear cut answers. Through raising awareness of the problems, exploring the applicability of principles already developed under international law disciplines, and promoting a cross fertilisation of ideas amongst lawyers from different disciplines, appropriate frameworks may be able to be developed before the worst predictions of global warming are realised.

\section{Ilona Millar}

Staff Lawyer, Climate Change and Energy Programme, Foundation for International Environmental Law and Development (FIELD) 